\title{
Investigation of Percolation-Driven Fluid Transport in Rock Salt under Repository-Relevant Conditions (PeTroS)
}

\author{
Christoph Lüdeling, Dirk Naumann, and Wolfgang Minkley \\ IfG Institut für Gebirgsmechanik GmbH, Friederikenstr. 60, 04279 Leipzig, Germany \\ Correspondence: Christoph Lüdeling (christoph.luedeling@ifg-leipzig.de)
}

Published: 10 November 2021

\begin{abstract}
According to the state of the art in mining and repository research, undisturbed rock salt is impermeable to fluids. Hence, rock salt formations are considered as host rock for nuclear waste repositories.

Viscous, polycrystalline salt rock with low humidity contains no connected pore spaces. Two mechanisms are known for fluid transport: (a) damage due to large deviatoric and tensile stresses generates dilatancy, and hence permeability. (b) Fluid pressure exceeding the minor principal stress can open pathways (pressure-driven percolation, Minkley et al., 2013). To assess barrier integrity of rock salt barriers, the dilatancy and minimal stress criteria have been derived.

Recently (Ghanbarzadeh et al., 2015; Lewis and Holness, 1996), high permeabilities in rock salt have been postulated under certain conditions. In particular, at high stresses and temperatures, including possible repository conditions, rock salt is claimed to develop a connected, thus permeable, pore space.

In the PeTroS project (Minkley et al., 2020), we investigated fluid transport in the supposedly permeable region. Five points in pressure-temperature space were defined - pressures of 18 and $36 \mathrm{MPa}$, temperatures of 140,160 , and $180^{\circ} \mathrm{C}$. At each point, experiments with both nitrogen and saturated $\mathrm{NaCl}$ solution (brine) were performed. Samples were prepared from natural rock salt of German Zechstein formations, both bedded and domal salt. Sample material was generally relatively pure rock salt with minor impurities.

Cylindrical samples (diameter $100 \mathrm{~mm}$, length $200 \mathrm{~mm}$ ) were loaded in a triaxial (Kármán) cell. Fluid pressure was applied to a central pressure chamber; any transmitted fluid was collected and extracted at the secondary side. The entire cell was heated to the specified temperature.

Experiments generally comprised an isotropic phase (several stages of fluid pressure almost up to the confining stress) and a fluid breakthrough phase (lowering of axial stress by strain-controlled extension). After the test, a coloured tracer fluid was injected to visualise fluid discharge points.

Fluid breakthroughs with fluid pressure above the minor principal stress were observed at all five pressuretemperature conditions. Some samples showed an approximately Darcian flow at fluid pressure below the minor principal stress, with permeabilities in the order of $10^{-22} \mathrm{~m}^{2}$, as is regularly observed due to the small size and initial damage from sample preparation (Popp et al., 2007). Tests consistently showed a gradual decrease of flow rate, i.e. reduction of the initial damage.

A stable permeability over longer times, as would be expected due to the formation of a connected pore space network, was not observed in any of the experiments. Intriguingly, experiments with brine showed no initial permeability even though the wetting fluid should plausibly favour the formation of a stable connected pore network.

Predictions of the static pore scale theory (Ghanbarzadeh et al., 2015) could thus not be confirmed. Regarding repositories for heat-generating waste, it can be concluded that from a geomechanical point of view, the dilatancy and minimal stress criteria are the relevant criteria for barrier integrity even at higher pressure and temperature.
\end{abstract}


Kurzfassung. Dem Stand der Technik in der Bergbau- und Endlagerforschung entsprechend ist Steinsalz im ungestörten Zustand für Fluide undurchlässig. Daher werden Steinsalzformationen als Wirtsgestein für Endlager für nukleare Abfälle in Betracht gezogen.

Viskoses, polykristallines Salzgestein mit geringem Feuchtegehalt enthält keinen zusammenhängenden Porenraum. Für den Fluidtransport sind zwei Mechanismen bekannt: (a) Schädigung durch deviatorische ode Zugspannungen erzeugt Dilatanz und damit Permeabilität. (b) Fluiddruck, der die minimale Hauptspannung übersteigt, kann Wegsamkeiten öffnen (druckgetriebene Perkolation, Minkley et al., 2013). Um die Integrität von Steinsalzbarrieren zu bewerten, wurden das Dilatanzkriterium und das Minimalspannungskriterium abgeleitet.

In jüngerer Zeit (Ghanbarzadeh et al., 2015; Lewis and Holness, 1996) wurden hohe Permeabilitäten in Steinsalz unter bestimmten Bedingungen postuliert. Insbesondere bei hohen Spannungen und Temperaturen, was auch mögliche Endlagerbedingungen einschließt, wird davon ausgegangen, dass in Steinsalz ein zusammenhängender und somit durchlässiger Porenraum entstehen kann.

Im PeTroS-Projekt (Minkley et al., 2020) untersuchten die Autoren den Fluidtransport in dem hypothetisch durchlässigen Bereich. Dazu wurden fünf Punkte im Druck-Temperatur-Raum definiert - Drücke von 18 und $36 \mathrm{MPa}$, Temperaturen von 140, 160 und $180^{\circ} \mathrm{C}$. An jedem Punkt wurden Experimente sowohl mit Stickstoff als auch mit gesättigter NaCl-Lösung (Lauge) durchgeführt. Proben wurden aus Material aus deutschen Zechsteinlagerstätten hergestellt, sowohl aus flacher wie aus steiler Lagerung. Das Probenmaterial bestand i. Allg. aus relativ reinem Steinsalz mit kleineren Beimischungen.

Zylindrische Proben (Durchmesser 100 mm, Länge 200 mm) wurden in eine triaxiale (Kármán-)Zelle geladen. Dann wurde eine zentrale Druckkammer mit Fluiddruck beaufschlagt; etwaige durchtretende Fluide wurden aufgefangen und auf der Sekundärseite entnommen. Die ganze Zelle wurde auf die festgelegte Temperatur aufgeheizt.

Die Versuche umfassten generell eine isotrope Phase (mehrere Fluiddruckstufen bis knapp unterhalb der Einspannung) und eine Phase des Fluiddurchbruchs (Verringerung der Axialspannung durch verformungsgeregelte Extension). Nach der Untersuchung wurde eine ein Farbtracer injiziert, um die Fluidaustrittsstellen sichtbar zu machen.

Fluiddurchbrüche mit einem Fluiddruck oberhalb der minimalen Hauptspannung wurden bei sämtlichen fünf Druck-Temperatur-Bedingungen festgestellt. Einige Proben wiesen einen annähernd darcyschen Fluss bei einem Fluiddruck unterhalb der minimalen Hauptspannung auf mit Permeabilitäten in einer Größenordnung von $10^{-22} \mathrm{~m}^{2}$, wie sie aufgrund der geringen Größe und der initialen Schädigung durch die Probenpräparation regelmäßig zu beobachten sind (Popp et al., 2007). Übereinstimmend zeigten die Untersuchungen eine allmähliche Abnahme der Flussrate, d. h. eine Verminderung der initialen Schädigung.

Eine stabile Permeabilität über längere Zeiträume, die aufgrund der Bildung eines zusammenhängenden Porenraumnetzes zu erwarten wäre, wurde bei keinem der Experimente festgestellt. Interessanterweise ergaben die Experimente mit Lauge keine initiale Permeabilität, obwohl ein benetzendes Fluid plausiblerweise die Bildung eines stabilen zusammenhängenden Porenraumnetzes begünstigen sollte..

Vorhersagen der „static pore-scale theory“ (Ghanbarzadeh et al. 2015) konnten somit nicht bestätigt werden. Im Hinblick auf Endlager für wärmeentwickelnde Abfälle kann die Schlussfolgerung gezogen werden, dass aus geomechanischer Sicht das Dilatanzkriterium und das Minimalspannungskriterium auch bei höherem Druck und höherer Temperatur die entscheidenden Kriterien für die Barriereintegrität darstellen.

Acknowledgements. The PeTroS research project was commissioned by the Federal Office for the Safety of Nuclear Waste Management (BASE) and funded by the Federal Ministry of the Environment, Nature Conservation and Nuclear Safety (BMU).

\section{References}

Ghanbarzadeh, S., Hesse, M. A., Prodanovic, M., and Gardner, J. E.: Deformation-assisted fluid percolation in rock salt, Science, 350, 1069-1072, https://doi.org/10.1126/science.aac8747, 2015.

Lewis, S. and Holness, M.: Equilibrium halite-H2O dihedral angles: High rock-salt permeability in the shallow crust? Geology, 24, 431-434, https://doi.org/10.1130/00917613(1996)024<0431:EHHODA>2.3.CO;2, 1996.

Minkley, W., Knauth, M., and Brückner, D.: Discontinuummechanical behaviour of salt rocks and the practical relevance for the integrity of salinar barriers, in: ARMA, 47th US Rock 
Mechanics Symposium, San Francisco, CA, USA, 23-26 June 2013, Paper ARMA 13-388, 2013.

Minkley, W., Lüdeling, C., and Naumann, D.: Überprüfung des perkolationsgetriebenen Transports von Fluiden im Wirtsgestein Steinsalz unter Bedingungen für ein Endlager (PeTroS), BfERESFOR-006/20; urn:nbn:de:0221-2020112023854, Abschlussbericht, Institut für Gebirgsmechnik GmbH. Leipzig, 2020.
Popp, T., Wiedemann, M., Kansy, A., and Pusch, G.: Gas transport in dry rock salt - implications from laboratory investigations and field studies, in: Proceeding of the 6th Conference on the Mechanical Behavior of Salt (SaltMech VI), Hannover 2007, Taylor \& Francis, London, https://doi.org/10.1201/97813151065023, 2007. 